\title{
Pratylenchus brachyurus (Nematoda: Pratylenchidae) on macadamia in Brazil
}

\author{
M. F. Bonfim Jr • A. C. Z. Machado • J. V. Araújo Filho
}

Received: 22 July 2011 / Accepted: 27 October 2011 /Published online: 24 November 2011

(C) Australasian Plant Pathology Society Inc. 2011

\begin{abstract}
Pratylenchus brachyurus was identified morphologically from root samples collected from a macadamia field in the municipality of Charqueada, located in southeastern São Paulo, Brazil. Low numbers of the nematode were recovered from samples collected from asymptomatic macadamia trees. To our knowledge, this is the first record of $P$. brachyurus on macadamia in Brazil and worldwide.
\end{abstract}

Keywords Root lesion nematode $\cdot$ Macadamia $\cdot$ Forest nematology $\cdot$ Identification

The macadamia nut (Macadamia integrifolia Maiden and Betche), native to south-eastern Queensland, Australia, is commercially produced mainly in Hawaii. Some countries in Latin America, Africa, Asia and in the United States of America (in California and Florida) also grow macadamia. Sao Paulo is the main macadamia producer in Brazil. Despite increasing acreage of macadamia, worldwide, virtually no information on nematode damage is available on this crop (El-Borai and Duncan 2005).

In April 2010, root samples were collected in a macadamia field in Charqueada, south-eastern São Paulo, Brazil $\left(22^{\circ} 30^{\prime} 35^{\prime \prime} \mathrm{S}, 47^{\circ} 46^{\prime} 41^{\prime \prime} \mathrm{W}\right)$. Roots were washed,

M. F. Bonfim Jr $(\bowtie) \cdot$ J. V. Araújo Filho

Departamento de Fitopatologia e Nematologia,

Escola Superior de Agricultura "Luiz de Queiroz",

Universidade de São Paulo,

C.P. 09,

13418-900 Piracicaba, SP, Brazil

e-mail: mauroferreirajr@yahoo.com.br

A. C. Z. Machado

Instituto Agronômico do Paraná,

86001-970 Londrina, PR, Brazil dried, cut in pieces and processed for nematode extraction by blender centrifugal flotation (Coolen and D'Herde 1972). Nematode populations were counted under a compound microscope (x 100) using a Peters slide counting chamber.

Morphological identifications were conducted on specimens killed in a water bath $\left(55^{\circ} \mathrm{C}\right)$ and fixed in formaldehyde $2 \%$ (Cobb 1918). Morphometrical characteristics and the De Man ratios $\left(\mathrm{V} \%, \mathrm{a}, \mathrm{b}, \mathrm{b}\right.$ ', c, and $\left.\mathrm{c}^{\prime}\right)$ were obtained from six adult females.

Characters measured were consistent with Pratylenchus brachyurus (Castillo and Vovlas 2007); the labial region showed two annuli, stylet was $16.8( \pm 1.2) \mu \mathrm{m}$ long, with stout, rounded basal knobs (Fig. 1a). Vulva position was $85.5 \%( \pm 3.1)$ of the body length; spermatheca were inconspicuous (Fig. 1b). Males were not found. The postvulval uterine sac was less than one body diameter $(20.2 \pm 1.6 \mu \mathrm{m})$ long and tail was $(26.5 \pm 3.4 \mu \mathrm{m})$ broadly conoid, smooth, with a broadly rounded, truncate tip (Fig. 1b). Pharyngeal overlapping length was 112.3 ( \pm 17.2$)$ $\mu \mathrm{m}$; pharynges were $158.8( \pm 17.8) \mu \mathrm{m}$ in length. The De Man ratios obtained were: $a=26.0 \pm 4.2 ; \mathrm{b}=5.0 \pm 1.0$; $b^{\prime}=3.5 \pm 0.7 ; c=20.8 \pm 2.5 ;$ and $c^{\prime}=2.2 \pm 3.1$. Two permanent microscope slides of $P$. brachyurus were deposited in the IAPAR Nematode Collection (INC), Londrina, Paraná, Brazil, as acession numbers IPR-MAC-79 and IPRMAC-80.

To our knowledge, P. brachyurus is recorded for the first time on macadamia in Brazil. Since it is common to find maize, a good host for P. brachyurus, between the rows of macadamia, the present report is important for the growers to avoid crop losses. Macadamia does not seem to be affected by $P$. brachyurus, but further pathogenicity tests are necessary to confirm the percentage crop damage. 

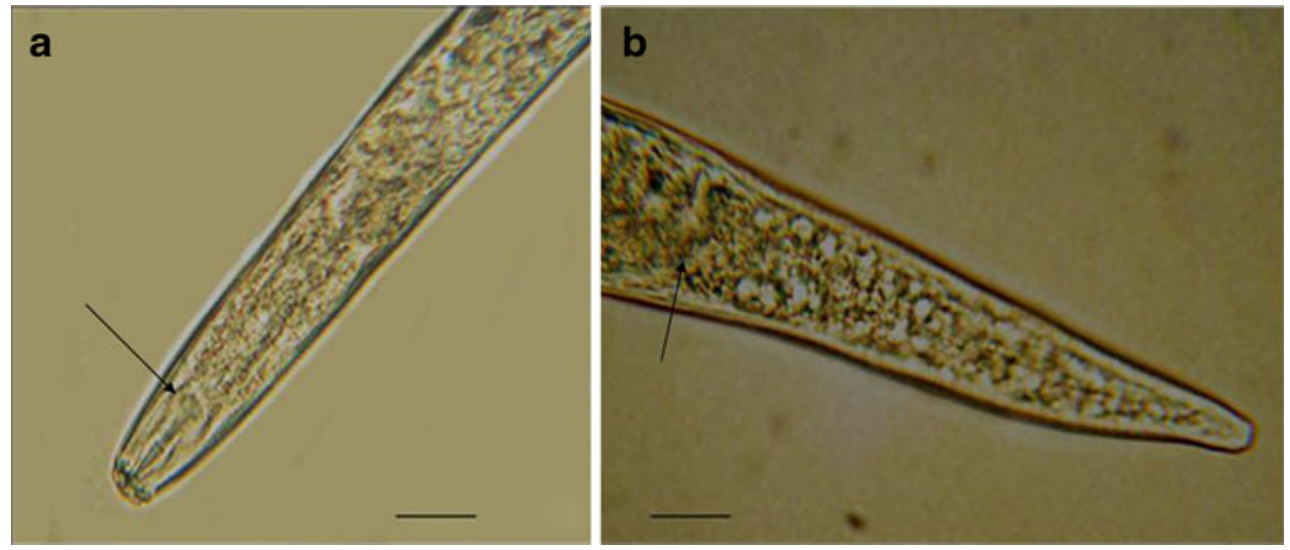

Fig. 1 Pratylenchus brachyurus extracted from macadamia roots. a Anterior region showing rounded basal knobs of stylet (arrow). b Truncate caudal terminus (arrow: terminal vulva). Bars $=18 \mu \mathrm{m}$

\section{References}

Castillo P, Vovlas N (2007) Pratylenchus (Nematoda: Pratylenchidae): diagnosis, biology, pathogenicity and management. Koninklijke Brill NV, Leiden

Cobb NA (1918) Estimating the nema population of the soil, with special reference to the sugar-beet and root-gall nemas, Heterodera schachtii Schmidt and Heterodera radicicola (Greef) Muller, and with a description of Tylencholaimus aequalis n.sp. USDA, Agricultural Technology Circular, Bureau Plant Industry, United States Department of Agriculture, pp. $1-48$

Coolen WA, D'Herde CJ (1972) A method for the quantitative extraction of nematodes from plant tissue. State Agricultural Entomology Research Station Ghent, Belgium

El-Borai FE, Duncan LW (2005) Nematode parasites of subtropical and tropical fruit tree crops. In: Luc M, Sikora RA, Bridge J (eds) Plant parasitic nematodes in subtropical and tropical agriculture, CABI Publishing, pp 467-492 